\title{
Performance of finisher broiler chickens fed diets containing unpeeled sweet potato meal as partial substitute for maize
}

*Odutayo, O. J., Sogunle, O. M., Safiyu, K. K., Olasupo, O. O. and Olaifa, R. O. Department of Animal Production and Health,

College of Animal Science and Livestock Production, Federal University of Agriculture Abeokuta, P.M.B 2240. Abeokuta, Ogun State, Nigeria

*Corresponding author: odutayooj@funaab.edu.ng; +2347069466240

Abstract

This study evaluated effects of unpeeled sweet potato meal (USPM) on performance of finisher broiler chickens. A total of 180 one day-old broiler chicks were used for the experiment. Brooding operation was carried out for 2 weeks. Thereafter, the broiler chickens were managed for additional 2 weeks with provision of starter diet and water ad-libitum. At four weeks old, they were equalized for weight and distributed into three dietary treatments (control, $10 \%$ and $15 \%$ unpeeled sweet potato meal as partial replacement for maize) each replicated four times with 15 birds per replicate; laid out in a completely randomized design. The birds were managed intensively throughout the experimental period until they attained 7 weeks of age. Data collected were subjected to one-way analysis of variance. Results revealed that the inclusion of unpeeled sweet potato meal up to 15\% in diets of finisher broiler chickens did not significantly affect the growth performance indices, haematological parameters, carcass traits and most of the serum metabolites except albumin which showed significant variation and ranged from $1.35 \mathrm{~g} / \mathrm{dl}(15 \%$ USPM) to $1.90 \mathrm{~g} / \mathrm{dl}$ (control). Least significant cost (N129.73) per kg feed was recorded in birds fed diet containing 15\% USPM relative to highest cost (N136. 63) per $\mathrm{kg}$ feed observed in birds fed control diet. Conclusively, incorporation of unpeeled sweet potato meal up to $15 \%$ in diet of finisher broiler chickens reduced cost per $\mathrm{kg}$ of broiler finisher diet and had no detrimental implications on growth performance, haematological parameters, serum metabolites and carcass traits in chickens.

Keywords: Broilers, sweet potato meal and performance

\section{Introduction}

Broiler chicken production is the fastest means of providing animal protein to the teeming world population due to the birds' efficient feed utilization, rapid weight gain, and short generation interval (FAO, 2010). However, in spite of the potential of broiler chicken production in ameliorating animal protein malnourishment in a developing country like Nigeria. It is still confronted with the challenge of increased production cost attributable to the cost of feeding the birds to acceptable market weight. High cost of conventional feed ingredients has sent lot of poultry farmers out of business as cost of feeding alone account for $60-75 \%$ of the total production cost in Nigeria. As a result of the critical role of energy in animal nutrition and the fact that it contributes about 45-60 \% (Tewe and Egbunike, 1992) of diet for different classes of livestock and poultry. The sustenance and expected increase in broiler production is subject to readily available sources of dietary energy necessary for formulating diets.

Maize is the most commonly used energy source in poultry feeds, there is however an increasing demand on its use by human population as food and commercial livestock feed millers for the manufacture of feed. This contributes to scarcity and increase in the unit cost of maize, making it 


\section{Sweet potato meal as maize substitutes}

unavailable all year round energy source for livestock feeding. Therefore, to compensate for scarcity and fluctuating price of maize, there is the need to consider alternative sources of energy like agroindustrial by products, starchy roots and tubers such as sweet potato, cassava for the poultry feed production to enhance protein production at comparatively cheaper rate. Sweet potato is cultivated in over 100 nations and ranked fifth among the most important food crops in the tropics (An, 2004). The root of sweet potato is a valuable source of carbohydrate, vitamins and micronutrients (Byamukama et al. 2003). The peel of sweet potato is also high in energy but low in protein (Adeyosoye et al. 2010). Several studies have been reported to indicate the positive influence of sweet potato meal in the diet of broiler as replacement for maize: Shoremin and Job (2000) found that sweet potato at a substitution of $45 \%$ can safely replace maize in pullet mash. Onyekwere et al. (2008) observed that inclusion of $20 \%$ sweet potato as dietary energy source in broiler chicken production have no adverse effects on broiler starter. Maphosa et al. (2003) administered 0, 20, 50, 75, and $100 \%$ sweet potato root meal to broilers chicken diet and found that $50 \%$ inclusion had no negative influence during the finisher phase. On the other hand, this dietary inclusion level of sweet potato root meal adversely influenced body gain, feed intake, and feed conversion of the broilers during the starter phase. Also, Ayuk and Essien (2009) fed diets containing 0 to $50 \%$ sweet potato root meal to broiler chickens and observed increased body weight gain up to $40 \%$ inclusion; however, there was a significant reduction at $50 \%$ level of substitution. Tewe (1994) replaced maize with oven-dried and sun-dried sweet potato root meal; and observed a reduction in body weight gain and nutrient utilization of birds fed the sweet potato root meal diets. Woolfe (1992) replaced 50 to $75 \%$ of maize in poultry feed with dried sweet potato flour without adverse effects on the growth of broilers. However, resulting from inconsistency in the recommended inclusion rates previously reported and due to the dearth of information on the utilization of the whole tuber of sweet potato as an alternative energy source. This study investigated performance of finisher broiler chickens fed diets containing whole tuber sweet potato meal as partial replacement for maize.

\section{Materials and methods Studylocation}

The experiment was undertaken at the Poultry unit of the Teaching and Research farm, and the Animal Products and Processing Laboratory of the Department of Animal Production and Health, Federal University of Agriculture, Abeokuta, Ogun State, Nigeria. The site falls within Latitude $7.2233^{\circ} \mathrm{N}$ and Longitude $3.4403^{\circ} \mathrm{E}$ (Google earth, 2016) and has a tropical humid climate.

\section{Experimental birds and management}

A total of 180, one-day old broiler chicks were purchased from a reputable hatchery (Zartech farm) in Ibadan, Oyo state, and used for the study for a period of 7 weeks. The birds were intensively managed in deep litter housing type all through the experimental period. Brooding operation was carried out for two weeks. Thereafter, the birds were managed for additional two weeks with provision of starter diet and water ad-libitum at the starter phase. At the finisher phase, the birds were fed with a compounded experimental diet containing unpeeled sweet potato meal as partial replacement for maize (Table 1). 
Odutayo, Sogunle, Safiyu, Olasupo and Olaifa

Table 1: Gross composition of experimental diet (Finisher phase)

\begin{tabular}{llll}
\hline Ingredients (\%) & $\begin{array}{l}\text { Diet } 1 \\
\text { (Control) }\end{array}$ & $\begin{array}{l}\text { Diet 2 } \\
\text { (10\% USPM) }\end{array}$ & $\begin{array}{l}\text { Diet 3 } \\
\text { (15\% USPM) }\end{array}$ \\
\hline Maize & 57 & 47 & 42 \\
Sweet potato(USPM) & - & 10 & 15 \\
Soyabean meal & 16 & 16 & 16 \\
Fish meal (72\%) & 1 & 1 & 1 \\
Groundnut cake & 13 & 13 & 13 \\
Breweries dried grain & 4.5 & 4.5 & 4.5 \\
Wheat offal & 5 & 5 & 5 \\
Salt (Nacl) & 0.25 & 0.25 & 0.25 \\
Bone meal & 1.5 & 1.5 & 1.5 \\
Oyster shell & 1 & 1 & 1 \\
*Premix (finisher) & 0.25 & 0.25 & 0.25 \\
Lysine & 0.25 & 0.25 & 0.25 \\
Methionine & 0.25 & 0.25 & 0.25 \\
Total & $\mathbf{1 0 0}$ & $\mathbf{1 0 0}$ & $\mathbf{1 0 0}$ \\
Calculated composition & & & \\
ME (Kcal/kg) & 2906.75 & 2898.58 & 2894.50 \\
Crude protein (\%) & 20.79 & 20.17 & 19.87 \\
Ether extact (\%) & 4.62 & 4.64 & 4.65 \\
Crude fibre (\%) & 4.04 & 3.81 & 3.70 \\
Ash (\%) & 2.80 & 2.67 & 2.61 \\
\hline U⿻ & & &
\end{tabular}

UPSM $=$ Unpeeled sweet potato meal

*Premix contains per $2.5 \mathrm{~kg}$ /tonne: Vitamin A: 10,000,000 I.U; Vitamin D3: 2,000,000 I.U; Vitamin E: 40,000 mg; Vitamin K3: 2,000 mg; Vitamin B1: 1,50 0 mg; Vitamin B2: 5,000 mg; Vitamin B6: 4,000 mg; Niacin: 40,000 mg; Vitamin 12: $20 \mathrm{mg}$; Calpan: 10,000 mg; Folic acid: 1,000 mg; Biotin: $100 \mathrm{mg}$; Anti -oxidant: 100,000 mg; Choline Chloride: 300, $00 \mathrm{mg}$; Manganese: 80,000 mg; Zinc: 60,000 mg; Iron: 40,000 mg; Copper: 80,000 mg; Iodine: 800 mg; Selenium: $200 \mathrm{mg}$; Cobalt: $300 \mathrm{mg}$.

Sourcing and processing of unpeeled sweet potato (Ipomea batata) meal

Tubers of sweet potatoes were purchased from a local market in Odeda Local Government Abeokuta Ogun state, Nigeria. These tubers were washed, sliced into smaller portions without peeling and sun dried for a week until they were brittle. Slices of the sun dried sweet potato were then ground to make unpeeled sweet potato meal (USPM). Proximate composition of sample of the unpeeled sweet potato meal was determined according to AOAC (2005).

\section{Description of treatments groups}

The experiment consists of three (3) experimental diets which are: control, diet containing $10 \%$ unpeeled sweet potato meal as replacement for maize and diet containing $15 \%$ unpeeled sweet potato meal as replacement for maize.

\section{Experimental layout and design}

At four weeks old, the 180 birds were balanced for weight and distributed into three dietary treatments, each replicated four times with 15 birds per replicate, laid out in a completely randomized design.

\section{Data collection}

\section{Growth performance indices}

Feed intake was recorded for each replicate. Feed left over was subtracted from the amount offered to the birds weekly to determine the feed intake.

Average weight gain per bird was calculated by deducing the difference between the final body weight and initial body weight and dividing this value by the number of birds per replicate.

Feed conversion ratio (FCR) was calculated by dividing the feed intake by the weight 


\section{Sweet potato meal as maize substitutes}

gain.

Mortality percent $=$

Number of dead birds per replicate $\quad x 100$

Total number of birds stocked per replicate

Determination of haematological and serum parameters

At 49 days of age, blood and serum samples were collected for the determination of haematological and serum biochemical parameter. Two birds of average age were selected from each replicate and tagged. About $3 \mathrm{ml}$ of blood sample were collected from each of the bird selected with the aid of syringe via the wing vein. The blood collected was placed into EDTA bottle (1.5 $\mathrm{ml})$ and plan bottle $(1.5 \mathrm{ml})$ for the evaluation of haematological parameters and serum metabolite according to procedures of Schalm et al. (1975) and Peters etal. (1982).

\section{Carcass analysis}

At the $49^{\text {th }}$ day of age, two (2) birds of average weight from each replicate were selected and fasted over night to clear the guts. They were slaughtered via neck slit and eviscerated for carcass evaluation. The dressed weight was determined and expressed as a percentage of the live weight. Cut up parts and internal organs were also weighed and expressed as percentages of the live weight.

\section{Evaluation of cost benefit indices}

The prevailing market costs of feed ingredient at the time of the experiment were used to calculate the cost benefit parameters.

Daily cost of feed intake/bird $(\mathrm{N})=$ daily feed intake $\mathrm{x}$ cost per unit of feed Total feed cost / bird (finisher phase) $(\mathrm{N})=$ total feed inake at the finisher phase $\mathrm{x}$ unit cost of feed

Feed cost per weight gain $(\mathrm{N})=$ feed conversion ratio $\mathrm{x}$ feed cost per $\mathrm{kg}$

\section{Statistical analysis}

Data collected were subjected to one way Analysis of variance using the general linear model at 5\% level of significance as contained in MINITAB17 and significantly different means were separated using Tukey Test also in the same statistical package.

\section{Results and Discussion}

The proximate composition of unpeeled sweet potato meal is presented in Table 2 . The values for the crude protein, crude fibre, ether extract, ash and nitrogen free extract (NFE) were $2.76 \%, 1.45 \%, 4.25 \%$ and $80.79 \%$ while the dry matter and Metabolisable energy (ME) were $91.50 \%$ and $3314.84 \mathrm{kcal} / \mathrm{kg}$. Values obtained for the proximate compositions were consistent with that reported by previous authors: Aduku (2005); Sankaran et al. (2008); Ukom et al. (2009); Omodamiro et al. (2013); Beckford et al. (2015) and Dako et al. (2016).

Table 2: Proximate composition of unpeeled sweet potato meal (USPM)

\begin{tabular}{ll}
\hline Parameters (\%) & USPM \\
\hline Dry matter & 91.50 \\
Crude protein & 2.76 \\
Crude fibre & 1.45 \\
Ether extract & 4.25 \\
Ash & 2.25 \\
NFE & 80.79 \\
ME (Kcal/kg) & 3314.84 \\
\hline
\end{tabular}

USPM $=$ Unpeeled sweet potato meal 


\section{Odutayo, Sogunle, Safiyu, Olasupo and Olaifa}

The effect of unpeeled sweet potato meal (USPM) as partial replacement for maize on growth performance parameters of finisher broiler chickens is presented in Table 3. The vary inclusion levels of unpeeled sweet potato meal did not significantly influence $(\mathrm{P}>0.05)$ any of the growth performance indices. Final body weight ranged from 1724.40 (10\% USPM) to $1819.20 \mathrm{~g} / \mathrm{bird}$ (control); daily weight gain ranges from $38.51(10 \%$ USPM) to $43.14 \mathrm{~g} /$ bird (control). Feed conversion ratio ranged from 2.80 (control) to 3.29 (10\% USPM) while the lowest mortality rate of $0.74 \%$ was obtained in birds fed diet containing $15 \%$ USPM as against $1.48 \%$ observed in birds fed the control diet. Statistically similar results in the growth performance indices indicated that the utilization of unpeeled sweet potato meal as partial replacement for maize in broiler finisher diets up to $15 \%$ did not negatively affect the growth rates, as it stimulated similar growth responses in the finisher broiler chickens. This result was similar to the reports of Ayuk and Essien (2009) and Tamir and Tsega (2009) who observed no significant differences in the daily feed intake, weight gain, feed conversion ratio, and mortality rates of broiler chickens fed diets containing sweet potato as replacement for maize.

Table 3: Effect of unpeeled sweet potato meal on growth performance indices of finisher broiler chickens

\begin{tabular}{llllll}
\hline Parameter & $\begin{array}{l}\text { Diet 1 } \\
\text { (Control) }\end{array}$ & $\begin{array}{l}\text { Diet 2 } \\
(\mathbf{1 0 \%} \text { USPM) }\end{array}$ & $\begin{array}{l}\text { Diet 3 } \\
(\mathbf{1 5 \%} \text { USPM) }\end{array}$ & SEM & p-value \\
\hline Initial weight (g/bird) & 913.33 & 915.56 & 912.22 & 1.43 & 0.317 \\
Final weight (g/bird) & 1819.20 & 1724.40 & 1762.40 & 48.70 & 0.435 \\
Weight gain (g/bird/day) & 43.14 & 38.51 & 40.48 & 2.30 & 0.417 \\
Feed intake (g/bird/day) & 120.87 & 126.87 & 123.34 & 2.24 & 0.244 \\
Feed conversion ratio & 2.80 & 3.29 & 3.05 & 0.18 & 0.220 \\
Mortality (\%) & 1.48 & 2.22 & 0.74 & 1.21 & 0.708 \\
\hline
\end{tabular}

USPM: Un-peeled sweet potato meal

Haemaological parameters are used to evaluate health status of animals and to assess the degree of environmental, nutritional and pathological stress (Afolabi et al., 2010). Table 4 shows the influence of unpeeled sweet potato meal (USPM) on haematological and serum biochemical parameters of finisher broiler chickens. All the haematological indices evaluated revealed no significant $(\mathrm{P}>0.05)$ variations as a result of the dietary treatments. The packed cell volume (PCV) ranged from 30.00 (control) to $33.50 \%$ (15\% USPM), haemoglobin $(\mathrm{Hb})$ fell within 9.65 (control) to $10.40 \mathrm{~g} / \mathrm{dL}$ (15\% USPM), the red blood cell (RBC) obtained ranges from $2.10(10 \%$ USPM) to $2.25 \times 10^{12} / \mathrm{L}$ (control), while white blood cell (WBC) lowest value of $11.55 \times 10^{9} / \mathrm{L}$ was noted in bird fed $10 \%$
USPM and the highest WBC count of $11.85 \times 10^{9} / \mathrm{L}$ was recorded in birds fed the control diet. The ranges of haematological indices recorded in the study were within the normal reference values stipulated in literatures for domestic poultry (Schalm et al., 1975; Mitruka and Rawnsley 1977; Islam et al., 2004) suggesting that replacing maize with unpeeled sweet potato meal up to $15 \%$ did not predispose the finisher broiler chickens to anaemia or any health challenge as normal haematological parameters of an animal are direct indication of absence of disease (Olafedehan 2010).

Serum biochemical indices are used for the detection of organ diseases in domestic animals (Malik et al., 2013) and the amount of available protein in the diets. It has been 


\section{Sweet potato meal as maize substitutes}

reported that serum biochemical constituents are positively correlated with the quality of the diet (Adeyemi et al., 2000). With the exception of serum albumin, no significant $(\mathrm{P}>0.05)$ differences were observed in the serum biochemical indices as a result of the utilization of unpeeled sweet potato meal as partial replacement for maize in the dietary treatments. The significantly $(\mathrm{P}<0.05)$ highest serum albumin value of $1.90 \mathrm{~g} / \mathrm{dl}$ was obtained in birds fed the control diet as against $1.35 \mathrm{~g} / \mathrm{dl}$ recorded in birds fed diet containing $15 \%$ USPM. The range of value obtained for serum albumin is consistent with that of Bounus et al. (2000) for normal healthy chickens $(1.1$ to $2.1 \mathrm{~g} / \mathrm{dl})$. The non significance differences observed in the serum globulin, total protein and the fact that it fell within the normal range as well as the albumin values, indicated that there was normal protein metabolism. This depicts nutritional sufficiency of the diets and safety of the test ingredient (unpeeled sweet potato meal) for finisher broiler chickens, thus there was absence of muscle degeneration in the birds. Statistical similarities observed in the liver enzymes (AST and ALT) which were within the normal reference values showed that there was no liver damage caused by toxicity from unpeeled sweet potato meal (Ekpenyong and Biobaku, 1986). Values obtained for all serum metabolites were within the normal reference ranges reported for healthy domestic chicken according to Mitruka and Rawnsley (1977).

Table 4: Effect of unpeeled sweet potato meal on haematological and serum parameters of finisher broiler chickens

\begin{tabular}{llllll}
\hline Parameter & $\begin{array}{l}\text { Diet 1 } \\
\text { (Control) }\end{array}$ & $\begin{array}{l}\text { Diet 2 } \\
(\mathbf{1 0 \%} \text { USPM) }\end{array}$ & $\begin{array}{l}\text { Diet 3 } \\
(\mathbf{1 5 \%} \text { USPM) }\end{array}$ & SEM & p-value \\
\hline PCV (\%) & 30.00 & 31.00 & 33.50 & 3.07 & 0.733 \\
$\mathrm{Hb}(\mathrm{g} / \mathrm{dl})$ & 9.65 & 10.00 & 10.40 & 0.83 & 0.827 \\
RBC (x 10 $\left.{ }^{12} \mathrm{l}\right)$ & 2.25 & 2.10 & 2.20 & 0.29 & 0.934 \\
WBC (x 10 1 ) & 11.85 & 11.55 & 11.70 & 1.20 & 0.985 \\
Heterophils (\%) & 27.00 & 27.50 & 34.00 & 7.10 & 0.759 \\
Lymphocytes (\%) & 73.00 & 69.50 & 63.50 & 7.34 & 0.686 \\
Eosinophils (\%) & 0.00 & 1.00 & 1.00 & 0.58 & 0.465 \\
Basophils (\%) & 0.00 & 0.50 & 0.50 & 0.41 & 0.650 \\
Monocytes (\%) & 0.00 & 1.50 & 1.00 & 0.30 & 0.074 \\
Total protein (g/dL) & 3.55 & 3.05 & 2.60 & 0.47 & 0.460 \\
Albumin (g/dL) & $1.90^{\mathrm{a}}$ & $1.45^{\mathrm{b}}$ & $1.35^{\mathrm{b}}$ & 0.07 & 0.023 \\
Globulin (g/dL) & 1.65 & 1.60 & 1.25 & 0.41 & 0.776 \\
Glucose (g/dL) & 149.00 & 155.00 & 118.00 & 13.90 & 0.277 \\
ALT (U/l) & 25.00 & 27.00 & 27.00 & 4.80 & 0.945 \\
AST (U/l) & 63.50 & 60.00 & 57.50 & 6.72 & 0.828 \\
\hline SEM: Stan
\end{tabular}

SEM: Standard error of mean; PCV: Packed cell volume; Hb: Haem oglobin; RBC: Red blood cells; WBC: white blood cell. USPM: Un-peeled sweet potato meal

The effect of unpeeled sweet potato meal on carcass characteristics of finisher broiler chickens is presented in Table 5. There were no significant $(\mathrm{P}>0.05)$ variations in all the carcass traits measured which is consistent with results obtained in the growth indices; indicating that nutrients supplied by the dietary treatments were adequate to results into similar carcass traits in the finisher broiler chickens. This result is similar to that of Beckford and Bartlett (2015) who observed no significance differences in the pre-slaughter weight, carcass weight, dressing percentage and retail cut-up parts of broiler chickens fed varying levels (10, 20 and $30 \%$ ) of sweet potato meal as replacement for maize. 
Odutayo, Sogunle, Safiyu, Olasupo and Olaifa

Table 5: Effect of unpeeled sweet potato meal on carcass traits of finisher broiler chickens

\begin{tabular}{|c|c|c|c|c|c|}
\hline Parameter & $\begin{array}{l}\text { Diet } 1 \\
\text { (Control) }\end{array}$ & $\begin{array}{l}\text { Diet } 2 \\
(10 \% \text { USPM) }\end{array}$ & $\begin{array}{l}\text { Diet } 3 \\
\text { (15\% USPM) }\end{array}$ & SEM & p-value \\
\hline Live weight (g) & 1866.67 & 1733.33 & 1800.00 & 61.60 & 0.372 \\
\hline Dressing $(\%)$ & 79.71 & 75.50 & 77.39 & 2.94 & 0.623 \\
\hline \multicolumn{6}{|l|}{ Cut-up parts ${ }^{1}$} \\
\hline$\overline{\text { Head }}$ & 2.38 & 2.72 & 2.50 & 0.25 & 0.629 \\
\hline Neck & 4.81 & 5.67 & 5.16 & 0.41 & 0.387 \\
\hline Wing & 7.97 & 7.84 & 7.99 & 0.29 & 0.927 \\
\hline Thigh & 10.87 & 9.16 & 10.99 & 1.26 & 0.554 \\
\hline Drumstick & 10.44 & 11.01 & 9.95 & 0.79 & 0.656 \\
\hline Shank & 3.49 & 4.04 & 3.62 & 0.32 & 0.479 \\
\hline Breast & 22.88 & 21.15 & 22.70 & 1.36 & 0.638 \\
\hline Back & 13.56 & 14.74 & 13.88 & 1.05 & 0.729 \\
\hline \multicolumn{6}{|l|}{ Viscerals $^{2}$} \\
\hline Heart & 0.36 & 0.38 & 0.34 & 0.02 & 0.566 \\
\hline Liver & 1.81 & 1.42 & 1.59 & 0.23 & 0.507 \\
\hline Spleen & 0.05 & 0.03 & 0.06 & 0.02 & 0.248 \\
\hline Gizzard & 2.63 & 2.29 & 2.46 & 0.15 & 0.335 \\
\hline
\end{tabular}

1,2: values expressed as percentages of the live weight

Means with different superscripts on the same row are significantly different $(\mathrm{p}<0.05)$; USPM: Un-peeled sweet potato meal

The cost benefit of partial replacement of maize with unpeeled sweet potato meal is presented in Table 6. It was observed that feed cost per $\mathrm{kg}$ diet was the only significant $(\mathrm{P}<0.05)$ parameter of all the cost benefit indices considered. The least significantly feed cost (N129. 73) per $\mathrm{kg}$ diet was obtained in birds fed diet containing 15\% USPM as against the highest feed cost per $\mathrm{kg}$ diet of N136. 63 in birds fed the control diet. This is an indication of the economic benefits of USPM when incorporated in the diet of finisher broiler chickens. Variation observed in the feed cost per $\mathrm{kg}$ diet is adduced to differences between the price per $\mathrm{kg}$ of N150.00 and N104.30 for maize and unpeeled sweet potato meal (USPM). This observation was contrary to the findings of Muhammad et al. (2012) who reported no significant differences in the cost per kg of feed of broiler chicken fed diet containing partially cooked sweet meal.

Also numerically lowest total feed cost per bird (N336.01) and daily feed cost per bird (N 16.00) were obtained in broiler chickens fed diet containing 15\% USPM when compared to that recorded in birds fed the control (N346; N16.514) and 10\% USPM (N351.74; N16.749) diets, respectively.

Table 6: Effect of unpeeled sweet potato meal on cost benefits of finisher broiler chickens

\begin{tabular}{|c|c|c|c|c|c|}
\hline Parameter & $\begin{array}{l}\text { Diet } 1 \\
\text { (Control) }\end{array}$ & $\begin{array}{l}\text { Diet } 2 \\
(10 \% \text { USPM) }\end{array}$ & $\begin{array}{l}\text { Diet } 3 \\
\text { (15\% USPM) }\end{array}$ & SEM & p-value \\
\hline Feed cost/kg ( $)$ & $136.63^{\mathrm{a}}$ & $132.03^{\mathrm{b}}$ & $129.73^{c}$ & 0.00 & 0.000 \\
\hline Total feed cost/bird ( & 346.80 & 351.74 & 336.01 & 6.19 & 0.262 \\
\hline Daily feed cost/bird ( & 16.514 & 16.749 & 16.000 & 0.29 & 0.262 \\
\hline Feed cost/kg gain $(\Downarrow)$ & 382.56 & 434.38 & 395.67 & 24.0 & 0.321 \\
\hline
\end{tabular}


Sweet potato meal as maize substitutes

\section{Conclusion}

Results from the study revealed that the incorporation of unpeeled sweet potato meal up to $15 \%$ in diet of finisher broiler chickens has no negative implications on growth performance, health status, carcass traits and also reduced cost per $\mathrm{kg}$ of feed in finisher broiler chickens.

\section{References}

Adeyemi, O. A., Fasina, O. E. and Balogun, M. O. 2000. Utilization of full fat jatropha seeds in broiler diet: Effect on Harmatological parameters and blood chemistry. Proceedings of the $25^{\text {th }}$ conference of Nigerian society of animal production held at Michael Opkara University of Agriculture, Umudike, 19-23 March, pp 108-109

Adeyosoye, O. I., Adesokan, I. A., Afolabi, K. D. and Ekeocha, A. H. 2010. Estimation of proximate composition and biogas production from in vitro gas fermentation of sweet potato (Ipomea batatas) and wild cocoyam (Colocasia esculenta) peels. African Journal of Environmental Science and Technology 4(6): 388-391

Aduku, A. O. 2005. Tropical Feedstuff Analysis Table. Department of Animal science, Ahmadu Bello University Zaria, Nigeria.

Afolabi, K. D., Akinsoyinu, A. O., Olajide, R. and Akinleye, S. B. 2010. Haematological parameters of the Nigerian local grower chickens fed varying dietary levels of palm kernel cake (p.247). Proceedings of 35 th Annual Conference of Nigerian Society for Animal Production.

Ayuk, E. A. and Essien, A. 2009. Growth and haematological response of broiler chicks fed graded level of sweet potato. International Journal of Poultry Science, 8(5): 485-488.

Beckford, R. C. and Bartlett, J. R. 2015. Inclusion levels of sweet potato root meal in the diet of broilers I. Effect on performance, organ weights, and carcass quality Poultry Science, 94(6):1316-1322.

Bounus, D. I. and Stedman, N. L. 2000. Normal avian haematology: Chicken and Turkey In: Feldman, B.F., Zinkle, J.G. and N.C. Jain Lippin Cott, Williams and Wilkins, Philadphia: 1174-1154.

Byamukama, E. R., Gibson, W., Aritua, V. and Adipala, E. 2003. Withincrop spread of sweet potato virus disease and the population dynamics of its whitefly and aphid vectors. Journal of Crop Protection, 23: 109116

Dako, E., Retta, N. and Desse, G. 2016. Comparison of three sweet potato (Ipomoea Batatas (L.) Lam) Varieties on Nutritional and AntiNutritional Factors Global Journal of Science Frontier Research: D Agriculture and Veterinary, 16(4): 63-72

Ekpenyong, T. E. and Biobaku, W. O. 1986. Growth response of rabbits fed activated sewage and dried poultry waste. Journal of Applied Rabbit Research, 1:14-16

Food and Agriculture Organization (FAO), 2010. Food and Agriculture Organization. Agribusiness handbook: Poultry meat and eggs. Viale delle Terme di Caracalla, 00153 Rome, Italy.

Google earth, 2016. Federal University of Agriculture. Retrieved from https://earth.google.com/web /@7.22330744,3.44033719,137.84 884575a,1046.69760578d,35y,100. $57030218 \mathrm{~h}, 44.99999706 \mathrm{t}$, - 


\section{Odutayo, Sogunle, Safiyu, Olasupo and Olaifa}

0r/data $=$ Cm4abBJmCiUweDEwM.

Islam, M. S., Lucky, N. S., Islam, M. R., Ahad, A., Das, B. D., Rahman, M. M. and Siddiq, M. I. 2004. Haematological parameters of Assil, Broiler and Local chickens reared in Sylhet region of Bangladesh. International Journal of Poultry Science, 3(2): 144-147.

Malik, S., Kumar, A., Verma, A., Gupta, M. K., Sharma, S. D., Sharma, A. K. and Rahal, A. 2013 . Haematological profile and blood chemistry in diarrhoeic calves affected with collibacillosis. Journal of Animal Health and Production, 1 (1):10-14

Maphosa, T., Gunduza, K. T., Jusina, J. and Mutungamiri, A. 2003. Evaluation of sweet potato tuber (Ipomea batatas L.) as a feed ingredient in broiler chicken diets. Livestock Research for Rural Development 15 (1): 252-262

Mitruka, B. M. and Rawnsley, H. M. 1977. Clinical, Biochemical and Haematological References Values in Normal Experimental Animals, Masson Publishing, USA. Inc. New York, pp. 83-109.

Muhammad, A. S., Adegbola, T. Adediwura, O. and Olayiwola, E. 2012. Growth performance of broiler chickens fed diets containing partially cooked sweet potato meal. Journal of Natural Sciences Research, 2(2) 50-60

Olafedehan, C. O., Obun, A. M., Yusuf, M. K., Ad ewumi, O. O., Olafedehan, C. O., Obun, A. M., Yusuf, M. K., Adewumi, O. O., Oladefedehan, A. O., Awofolaji, A. O. and Adeniji, A. A. 2010. Effects of residual cyanide in processed cassava peal meals on haematological and biochemical indices of growing rabbits. Proceedings of 35th Annual Conference of Nigerian Society for Animal Production. p. 212.

Peters, T., Biamonte, G. T. and Doumas, B. T. 1982. protein in serum. in: selected method of clinical chemistry. (G.W.R. Faulkner and S. Mcites, eds). American Association of Clinical Chemistry, pp 100-115

Sankaran, M., Singh, N. P., Santhosh, B., Datt, C., Prakash, J., Ngachan, S. V., Nedunchezhiyan, M., and Naskar, S. K. 2008. Production techniques and utilizetion of tuber Crops in Tripura. Technical Bulletin No: 37, Published by ICAR Research Complex for NEH Region, Tripura Centre, Lembucherra-799210, pp 1-33

Schalm, O. W., Jain, N. C. and Carol, E. J. 1975. Veterinary Haematology, $3^{\text {rd }}$ Ed. Lea and Fabiger, Philadelphia.

Shoremin, O. I. A. and Job, T. A. 2000. Utilization of dried sweet potato (lpomea batatas) in laying pullet diet. Proceeding of 25th Annual Conference with Nigeria Society of Animal Production

Tamir, B. and Tsega, W. 2009. Effects of different levels of dried sweet potato (Ipomoea batatas) leaves inclusion in finisher ration on feed intake, growth, and carcass yield performance of Ross broiler chicks. Tropical Animal Health and Production, 42: 687-695.

Tewe, O. O. and Egbunike, G. N. 1992. Utilization of cassava in nonruminant feeding" In: Cassava as Livestock Feed in Africa (S.K. Hahn, L. Reynoids and G.N. Egbunike, eds.). IITA, Ibadan and ILCA. Addis Ababa. pp. 28-38.

Tewe, O. O. 1994. Sweet potato utilisation 
in poultry diets. In: Symposium on tropical root crops in a developing economy, Ofori, F. and S.K. Hahn (Eds.). International Society for Horticultural Science, USA., pp: 426-435.

Woolfe, J. A. 1992. Sweet potato, an untapped feed resource. University Press. Cambridge, UK 643

Received: $6^{\text {th }}$ August, 2019

Accepted: $18^{\text {th }}$ December, 2019 